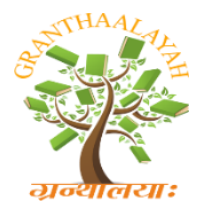

\author{
INTERNATIONAL JOURNAL OF RESEARCH - \\ GRANTHAALAYAH \\ A knowledge Repository
}

Science

\title{
THE PORTUGUESE NATIONAL INVENTORY ON PLANT GENETIC RESOURCES 2018 - DEVELOPMENT AND STATUS
}

\author{
Filomena Rocha *1 \\ ${ }^{* 1}$ Instituto Nacional de Investigação Agrária e Veterinária, I.P., Banco Português de \\ Germoplasma Vegetal (BPGV), Quinta de S. José, S. Pedro de Merelim, 4700-859 Braga. \\ Portuguese focal point for the European Cooperative Programme for Plant Genetic Resources \\ (ECPGR) Documentation \& Information Working Group
}

\begin{abstract}
Since the 1970s, Portugal has been endeavouring systematic and coordinated efforts for ex situ conservation of plant genetic resources. Portugal maintains in ex situ a large seed collection of cultivated species (cereals, fibres, grain legumes, vegetables), wild species (forages, MAP species), also national clone collections of olive, fruit trees and grapes. In 2011 the Portuguese National Genebank (BPGV) and ISOPLEXIS implemented the GRIN-Global platform, as provides the opportunity to increase data quality, to have long term sustainability for data curation, integrates all collections in one management system optimizing the costs and staff resources. Now, the main objective in Portugal is to implement the Grin Global Platform at the national level to consolidate its National Programme of Plant Genetic Resources (NPPGR) with all national partners directly involved in the conservation of PGR. The main objectives of this communication are: to demonstrate the valuable contribution of the Grin-Global platform to the NPPGR; discuss the development and status of the Portugal's National Inventory 2018 in EURISCO, analyse the evolution of the amount of passport information in EURISCO from 2015 to 2018; to address the steps that are being taken in Portugal for the Implementation of the Grin-Global Platform at the national level.
\end{abstract}

Keywords: Portugal; National Inventory; Grin-Global; EURISCO.

Cite This Article: Filomena Rocha. (2018). "THE PORTUGUESE NATIONAL INVENTORY ON PLANT GENETIC RESOURCES 2018 - DEVELOPMENT AND STATUS.” International Journal of Research - Granthaalayah, 6(11), 109-120. 10.29121/granthaalayah.v6.i11.2018.1094

\section{Introduction}

Portugal is located in Southwestern Europe, in the most western part of the Iberian Peninsula. The insular territories comprehend the Autonomous Regions of Azores and Madeira. Mainland Portugal is essentially integrated within the Mediterranean region, although the frontier between the latter and the Atlantic region crosses the country's extreme north-eastern. The Azores and Madeira Archipelagos are situated within the Macaronesian region (figure 1). 


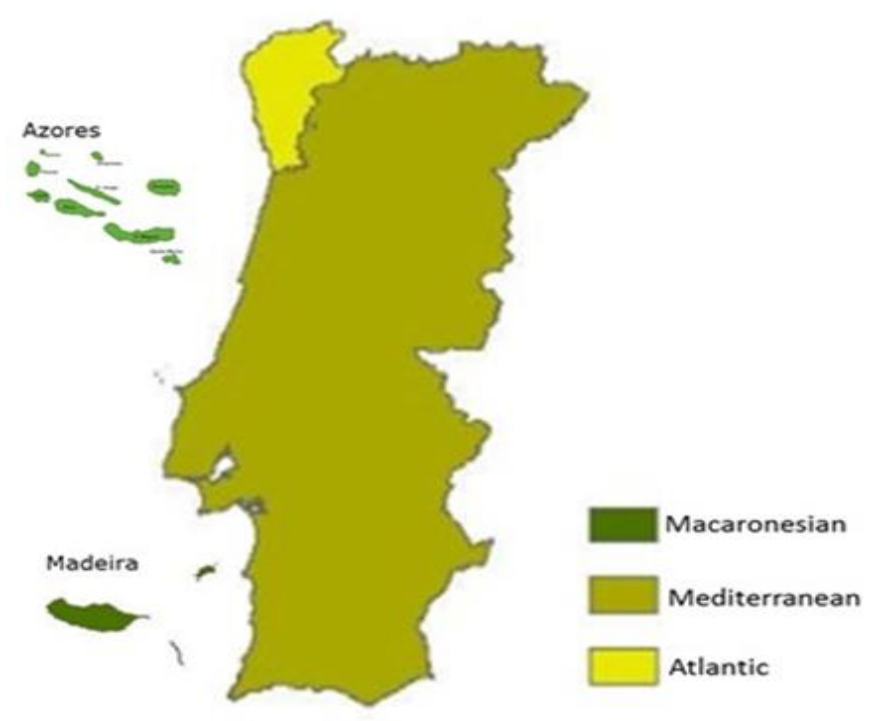

Figure 1: Portugal by terrestrial biogeographical regions

The geographical location and geophysical conditions of the Portuguese territory, shaped by human intervention, have led to a wide variety of biotopes, ecosystems and landscapes, more or less humanized, which are home to a rich range of autochthonous flora. About 3,600 species of plants occur in Portugal (ICNF, 1998). Portugal is also very rich in crop diversity as it is a secondary centre of diversity for several crops, has very particular traditional agricultural systems and traditional knowledge associated to those crops and agricultural systems.

Portugal has a large biodiversity in general and crop diversity in particular.

\section{Current Status of The Portuguese Ex Situ Crop Collections}

Since the 1970s, Portugal has been carrying out systematic and coordinated efforts for ex situ conservation of plant genetic resources:

- National and international collecting missions;

- In 1983, IBPGR, FAO appointed Portugal-BPGV as the responsible for the Maize Mediterranean collection;

- $\quad$ Signed in 2002 and ratified in 2005, the International Treaty on PGRFA;

- Portugal is a founding member (1980) of the European Cooperative Programme for Plant Genetic Resources (ECPGR);

- Within the framework of the ECPGR, Portugal participated in the development of the European Genebank Integrated System (AEGIS) and provide EURISCO Catalogue with updated passport information from the National Inventory (NI).

Plant genetic resources maintained in ex situ conditions, are mainly under the responsibility of public institutions, the Ministry of Agriculture, Forestry and Rural Development, and the Ministry of Education and Research. It is however noteworthy that over $80 \%$ of the genetic material of these collections is under the responsibility of the Ministry of Agriculture, Forestry and Rural Development, with the National Institute for Agrarian and Veterinarian Research, I.P. (INIAV) 
assuming a leadership role. Figure 2 summarizes the Portuguese ex situ crop collections' location, taking into account the collections that are maintained by each institution and the respective location.

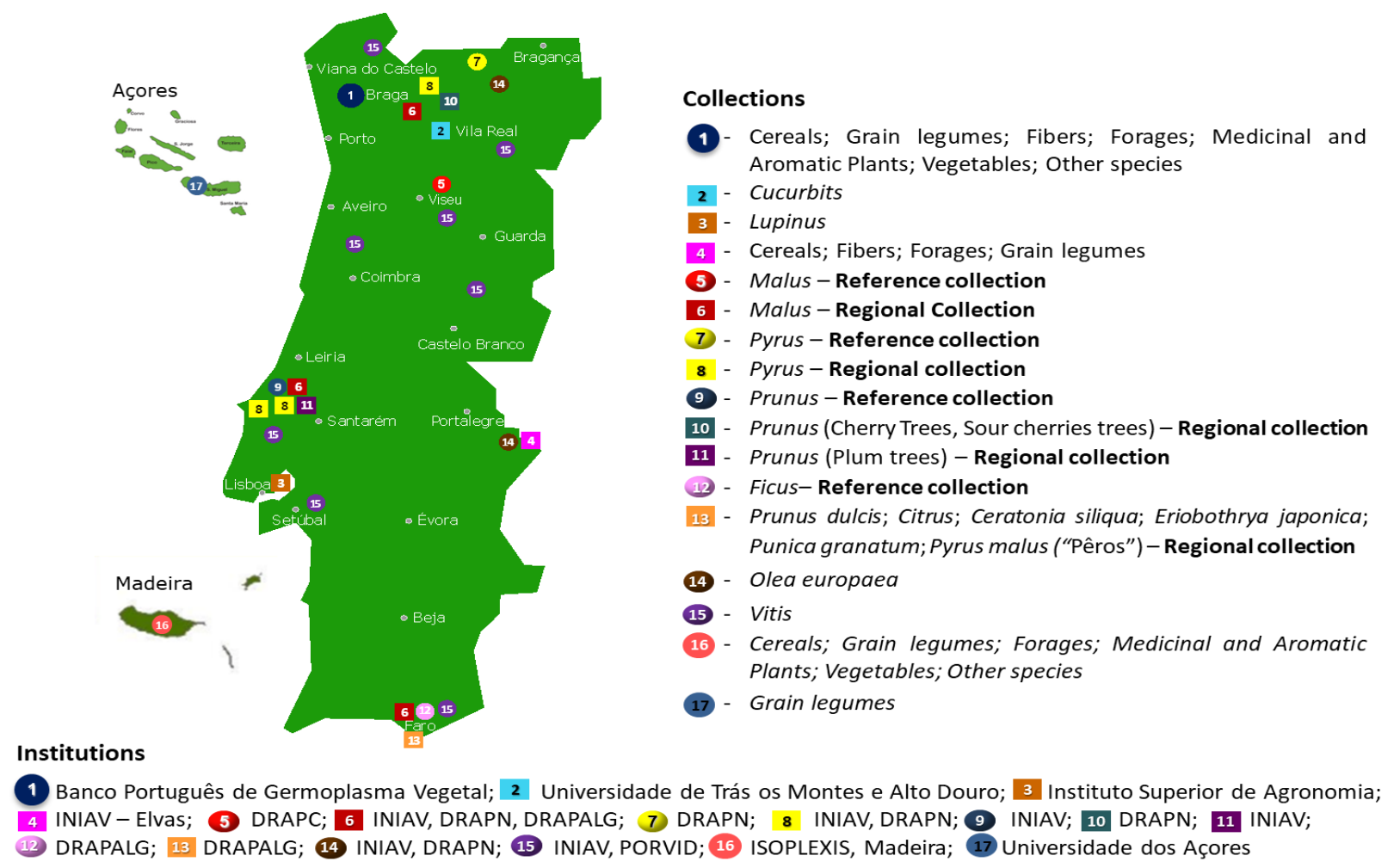

Figure 2: Portuguese ex situ crop collections location

On September 9, 2015 the "Programa Nacional para os Recursos Genéticos Vegetais" (INIAV, 2015b) was presented in a national public presentation (Figure 3).

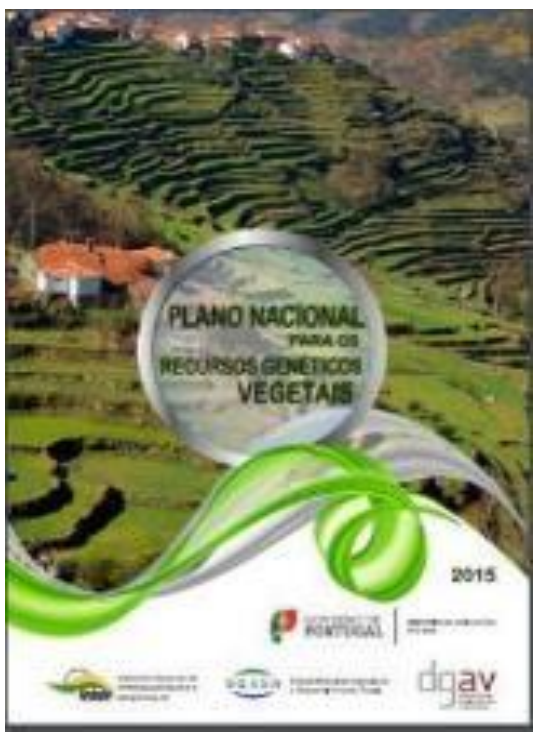

Figure 3: "Programa Nacional para os Recursos Genéticos Vegetais" 
INIAV was entrusted with the responsibility of the coordination of the conservation and sustainable use of genetic resources in Portugal.

During 2016-2017 the main goal was to integrate the other collections (material and data) in the BPGV, Braga (figure 4). Therefore, the seed collections that existed in the "Estação Agronómica Nacional" (PRT005) and in the "Estação Nacional de Melhoramento de Plantas" (PRT004) was integrate to the BPGV (PRT001).

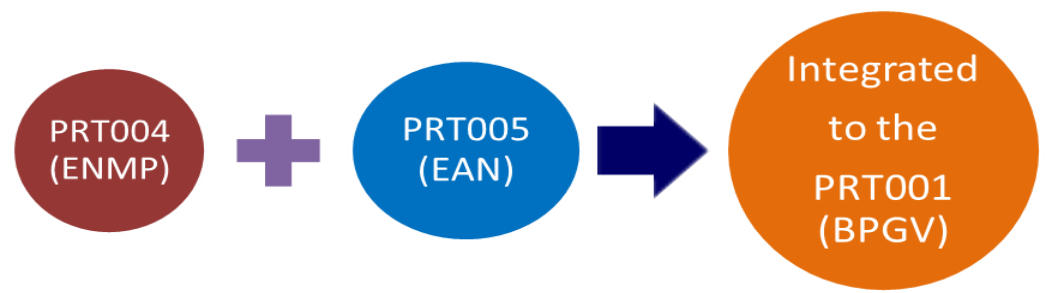

Figure 4: Integrated the seed collections that existed in the "Estação Agronómica Nacional" (PRT005) and in the "Estação Nacional de Melhoramento de Plantas" (PRT004) the other collections (material and data) in BPGV, Braga - National Genebank. (PRT001).

The International Treaty on Plant Genetic Resources for Food and Agriculture (ITPGRFA) was adopted on 3 November 2001 by the 31st Session of the Conference of the Food and Agriculture Organization of the United Nations (FAO) and entered into force on 29 June of 2004. Portugal signed the ITPGRFA in 2002 and ratified it in 2005.

The Article 17 - The Global Information System on Plant Genetic Resources for Food and Agriculture of the International Treaty on Plant Genetic Resources for Food and Agriculture, FAO 2009 (FAO, 2009), says:

Paragraph 1: "The Contracting Parties shall cooperate to develop and strengthen a Global Information System to facilitate the exchange of information, based on existing information systems, on scientific, technical and environmental matters related to PGR for food and agriculture, with the expectation that such exchange of information will contribute to the sharing of benefits by making information on PGR for food and agriculture available to all Contracting Parties. In developing the Global Information System, cooperation will be sought with the Clearing House Mechanism of the Convention on Biological Diversity".

However, as early as in 1992, the BPGV began computerizing activities related to the conservation of germplasm, databases were developed, centralized by species, with data records of collecting, characterization, regeneration and multiplication, germination, conservation and distribution (Rocha, 1999). In 1996, the National Institute for Agricultural Research (INIA), today INIAV, already at the time playing the leadership role in the coordination of the PGR national activities, implemented, maintained and run a national PGR documentation system, the National Information System on Plant Genetic Resources "(SNIRGV), (Bettencourt, 1996).

In order to fulfil this objective BPGV and ISOPLEXIS implemented a new database platform GRIN-Global in 2011 (Barata et al., 2014a; Pinheiro de Carvalho and Nóbrega, 2013). On 13 
February 2015, the BPGV officially launched a new information system to manage their precious plant genetic resources collections (Bioversity International, 2015; INIAV, 2015a).

GRIN-Global was developed by the USDA Agricultural Research Service, Bioversity International and the Global Crop Diversity Trust (GRIN-GLOBAL, 2018). GRIN-Global system components include: Administrator Tool, Curator tool, Search tool, Import Wizard, Middle Tier, Updater Application, and the Public Website. The GRIN-Global Website, provides "public" user access to the germplasm collections, and will deliver this information globally.

The main objective of the implementation of this platform in BPGV was to integrate all collections' data and related information, from BPGV in this GRIN-Global database platform, using international agreed standards for PGR. Today in the platform BPGV GRIN-Global already been inserted:

- Passport Data - 27,166 accessions; 143 genera; 336 taxa of 256 species

- Inventory - 32,662 samples

- Viability tests - 6,678 germination tests

- Crop characterization - 6 crop (common Bean, Coriander, Garlic, Onion, Parsley and Rye) - 36,867 observations

The link to the Grin-Global Website on BPGV can be found on the INIAV website (INIAV, 2018a) and also on the official Grin-Global page (GRIN-GLOBAL, 2018) (figure 5).
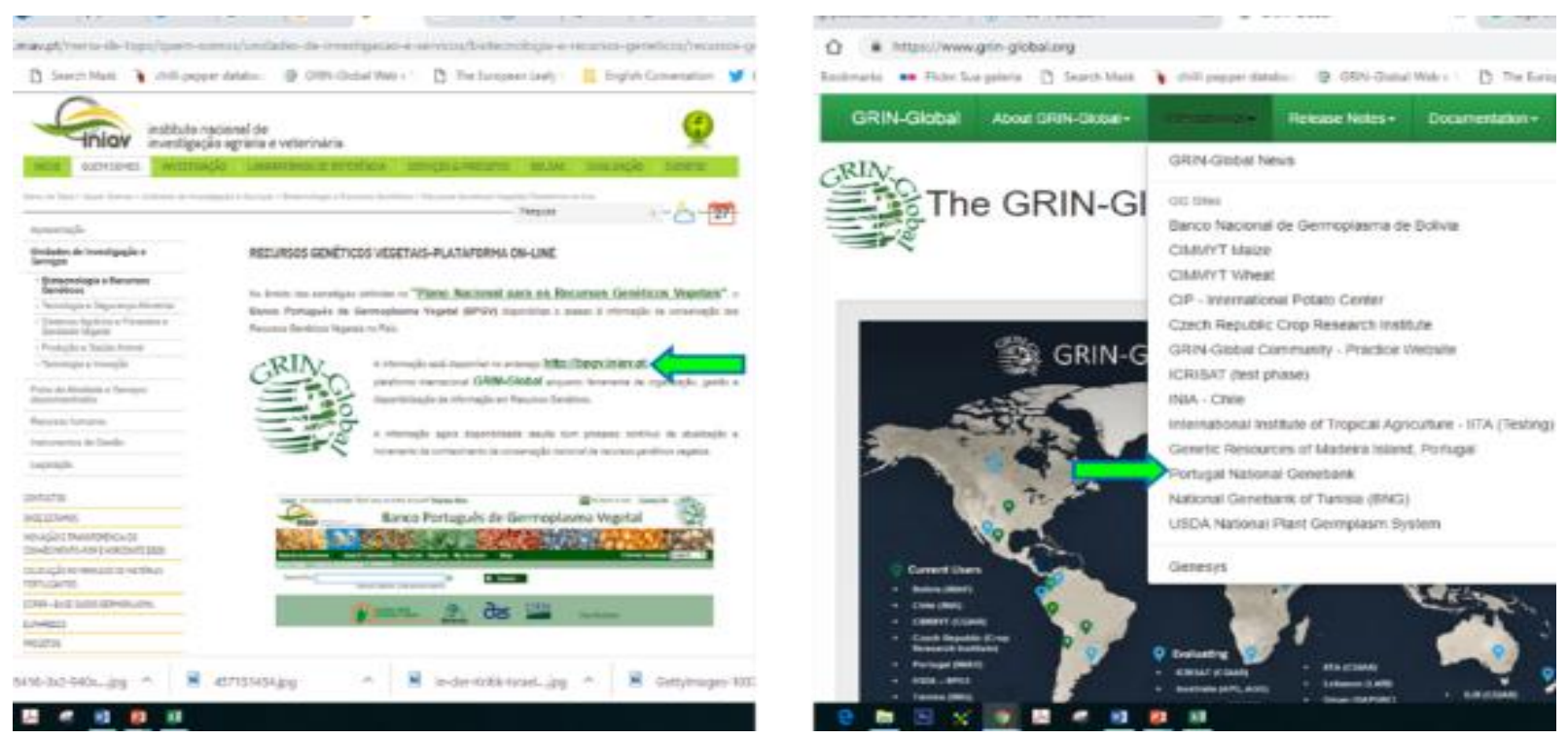

Figure 5: Grin-Global Website of BPGV can be found on the INIAV website and also on the official Grin-Global page

The type of information that is provided by GRIN-Global website in relation to germplasm collection of BPGV is shown in figure 6.

The BPGV GRIN-Global Website (INIAV, 2018b), provides "public" user access to the germplasm collections, and will deliver this information globally. 


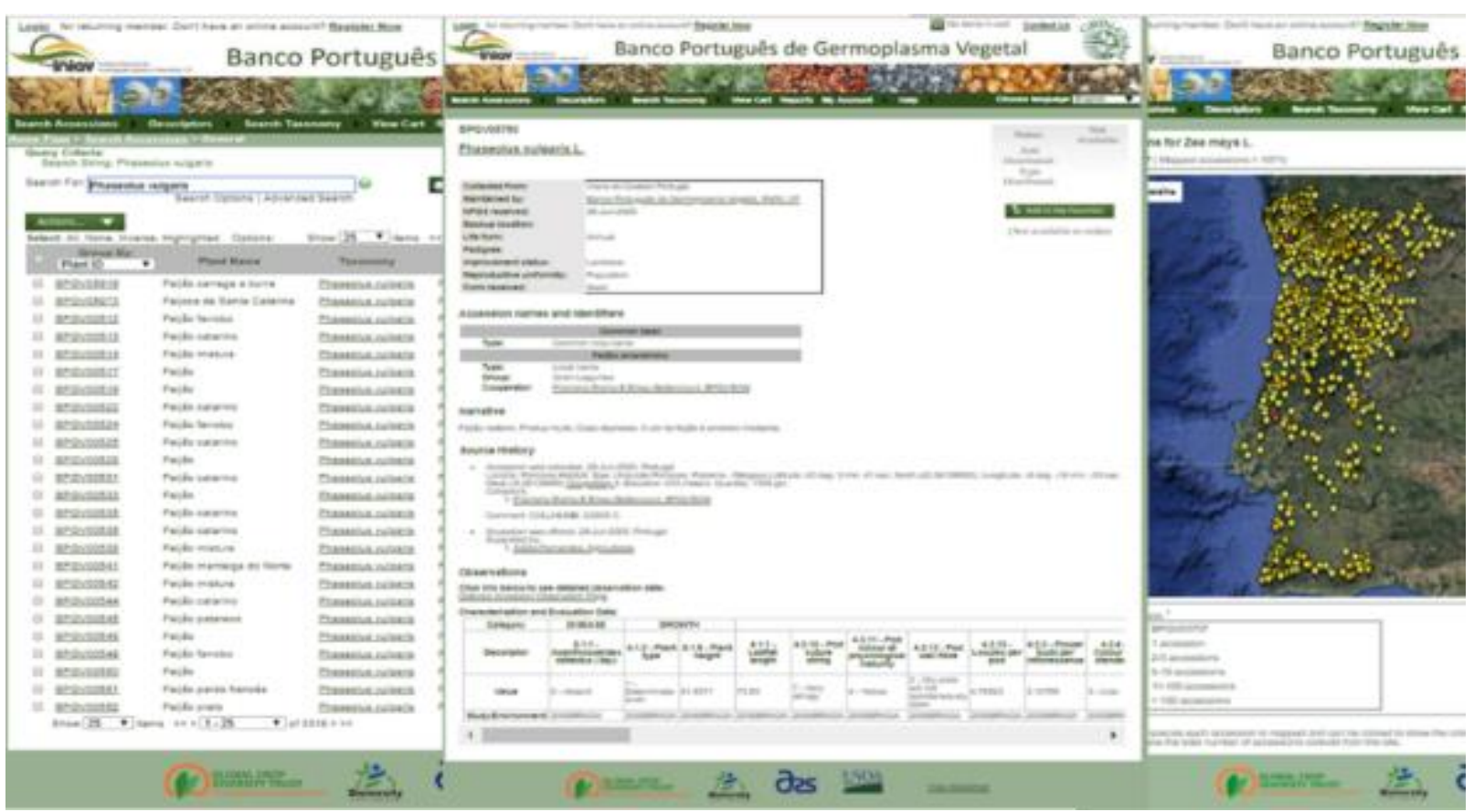

Figure 6: BPGV/INIAV GRIN-Global Website

In Grin-Global, using the Administrator tool, the descriptors were coded according to the FAO / Bioversity Multiple Passport Descriptors and then a Data View EURISCO in the Curator Tool was created. After, information is transferred to Excel and are ready to upload to EURISCO (figure 7).

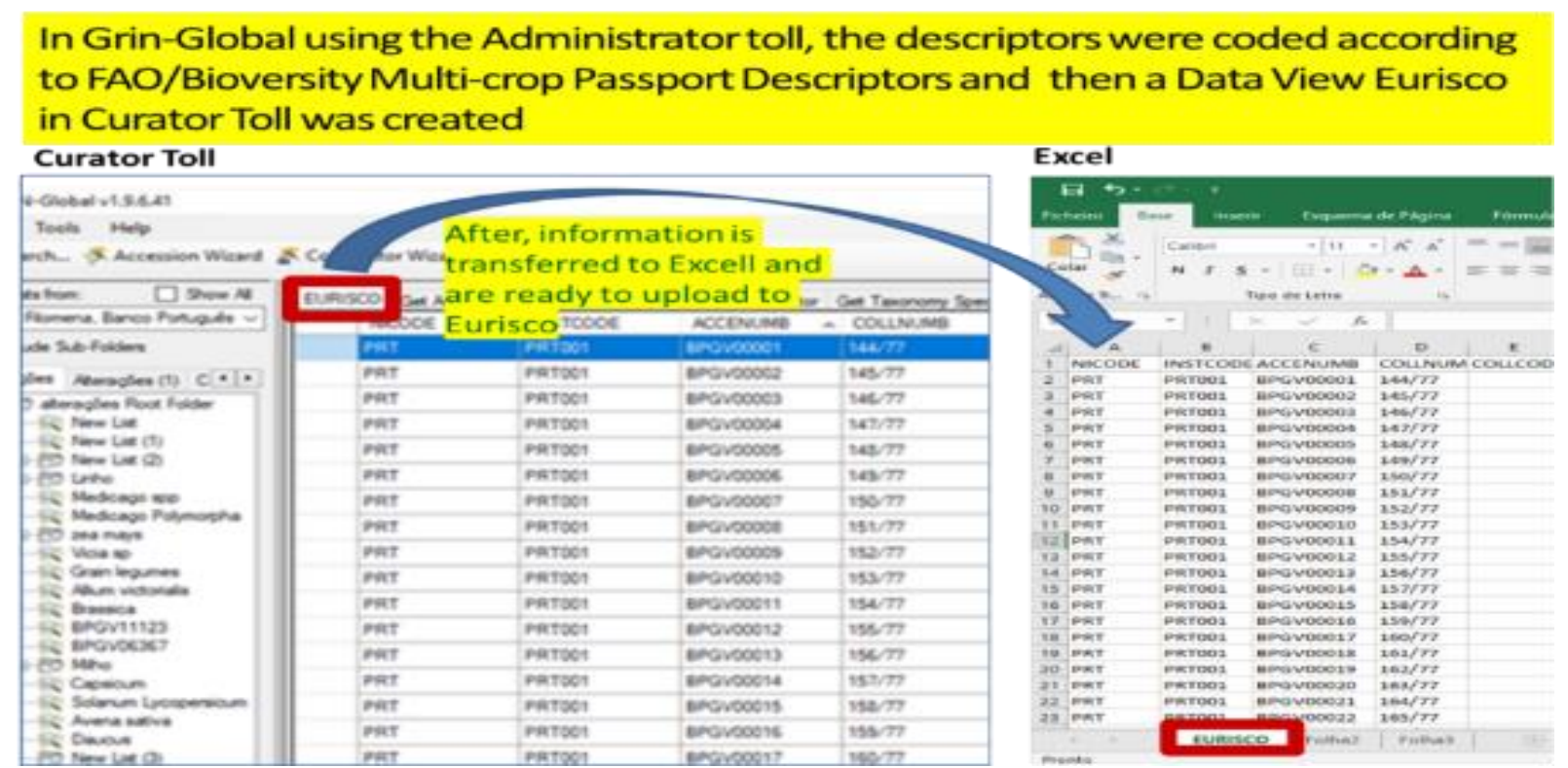

Figure 7: Following steps to transfer the passport data from Grin-Global platform to EURISCO

\section{Results and Discussion}

Currently, EURISCO contains passport data about 26,151 accessions of the Portuguese collections, maintained in 6 national institutions (Table 1). 
Analysing the Portuguese collections in EURISCO (EURISCO, 2018): Development and status, we verified that there was a great increase of the information made available. It went from 12,193 accessions, with passport data, that were registered until 2015 to 26,151 accessions with passport data in 2018, maintained in 6 (six) national institutions (Table 1).

Highlighted in yellow we can see that:

- The 5,285 accessions of the PRT005 (EAN) were all transferred and were integrated into PRT001 (BPGV)

- The 1,351 accessions of PRT004 (ENMP) were all transferred and were integrated into PRT001 (BPGV) and now PRT004 (ENMP) only maintains breeding collections

- Before the integration, a deep analysis of the accessions was made, and many accessions were identified in both PRT005 (EAN) and PRT004 (ENMP) as duplicates of the accessions already existing in PRT001 (BPGV). For this reason, it was necessary to give it the same BPGV accession number and to enter in the Grin-Global platform as samples of these accessions.

Table 1: Evolution of Portuguese Collection in EURISCO from 2015 to 2018

\begin{tabular}{|c|c|c|c|c|}
\hline $\begin{array}{l}\text { FAO } \\
\text { CODE }\end{array}$ & INSTITUTION & SPECIES GROUP & $\begin{array}{l}\text { ACCESSIONS } \\
\text { in } 2015\end{array}$ & $\begin{array}{r}\text { Accessions } \\
\text { in } 2017\end{array}$ \\
\hline PRT001 & $\begin{array}{l}\text { BPGV - Banco Português de } \\
\text { Germoplasma Vegetal/INIAV, Braga }\end{array}$ & Cereals; Vegetables & 3,389 & 23,983 \\
\hline PRT004 & $\begin{array}{l}\text { ENMP - Estação Nacional Melhoramento } \\
\text { Plantas, Elvas }\end{array}$ & $\begin{array}{l}\text { Cereals; Fibers; Forages; Grain } \\
\text { legumes }\end{array}$ & 1,351 & \\
\hline PRT005 & $\begin{array}{l}\text { EAN - Banco de Germoplasma, Estação } \\
\text { Agronómica Nacional, Oeiras }\end{array}$ & $\begin{array}{l}\text { Cereals; Fibers; Forages; Grain } \\
\text { legumes; MAPs; Vegetables }\end{array}$ & 5,285 & \\
\hline PRT018 & $\begin{array}{l}\text { ISA - Instituto Superior de Agronomia, } \\
\text { Lisboa }\end{array}$ & Grain legumes & 648 & 648 \\
\hline PRT025 & $\begin{array}{l}\text { UTAD - Universidade Trás-os-Montes e } \\
\text { Alto Douro, Vila Real }\end{array}$ & Vegetables & 65 & 65 \\
\hline PRT051 & $\begin{array}{l}\text { EVN - Estação Vitivinícola Nacional, } \\
\text { Dois Portos }\end{array}$ & Vitis & 721 & 721 \\
\hline PRT102 & $\begin{array}{l}\text { ISOPLEXIS - Banco de Germoplasma - } \\
\text { Universidade da Madeira }\end{array}$ & Forage, Grain legumes & 684 & 684 \\
\hline \multirow[t]{2}{*}{ PRT201 } & $\begin{array}{l}\text { Banco do Centro de Biotecnologia dos } \\
\text { Açores }\end{array}$ & Grain legumes & 50 & 50 \\
\hline & TOTAL & & 12,193 & 26,151 \\
\hline
\end{tabular}

The 5,285 accessions of the PRT005 (EAN) were all transferred and was integrated to the PRT001 (BPGV) The 1,351 accessions of PRT004 (ENMP) were all transferred and was integrated to the PRTO01 (BPGV) and now PRTO04 (ENMP) only have breeding collections.

The most represented Institution in terms of number of accessions, are PRT001 (BPGV) (23,983 accessions), followed by PRT051 (EVN - Estação Vitivinícola Nacional, Dois Portos) (721 accessions), PRT102 (ISOPLEXIS) (684 accessions), PRT018 (ISA) (648 accessions), PRT025 (UTAD) (65 accessions) and PRT201 (UAçores) (50 accessions). (Figure 8)

We can see also that in BPGV the most representative collection is cereals, followed by grain legumes, vegetables and forages/pastures. 


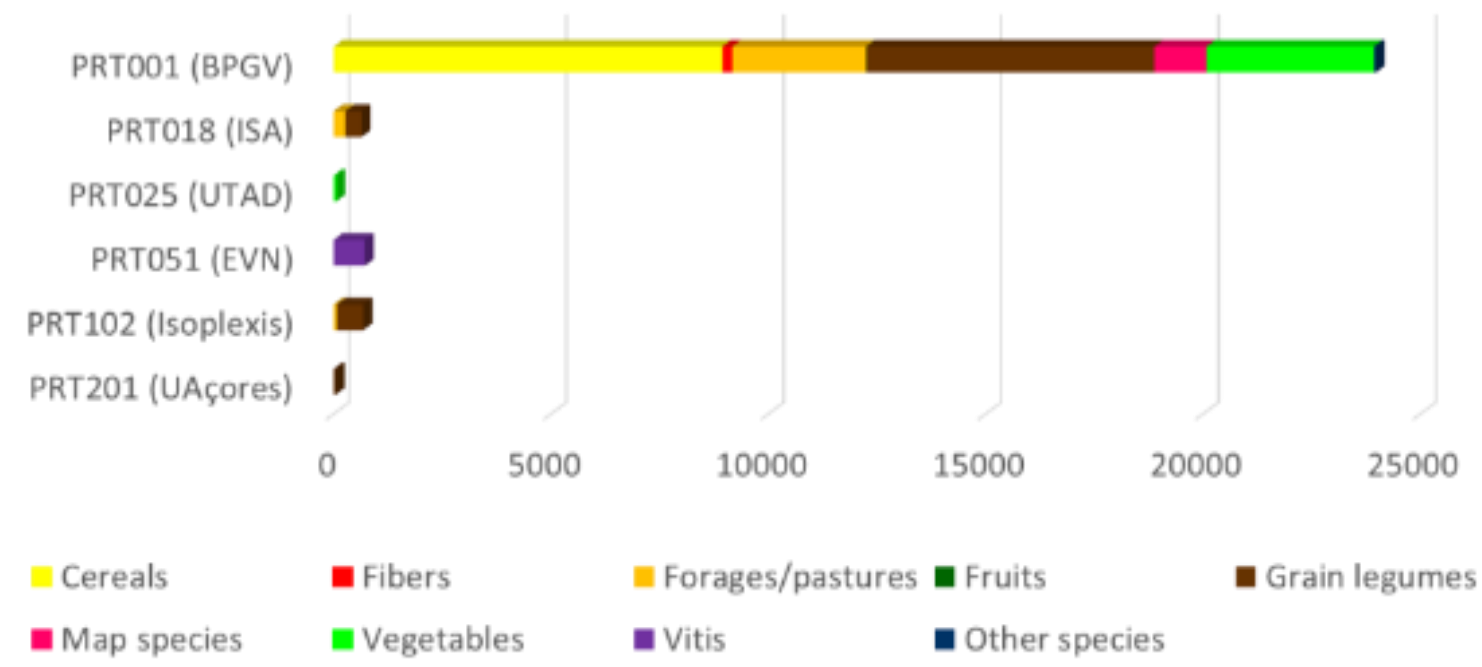

Figure 8: Portuguese collections in EURISCO: Number of accessions by FAO codes and species' group

The most represented species' groups in terms of "number of accessions", are Cereals $(8,940$ accessions) and Grain legumes (7,657 accessions), followed by Vegetables (3,926 accessions), Forages/pastures (3,428 accessions), MAP species (1,198 accessions), Vitis (721 accessions), Fibers (229 accessions) and Fruits (9 accessions) (Figure 9)

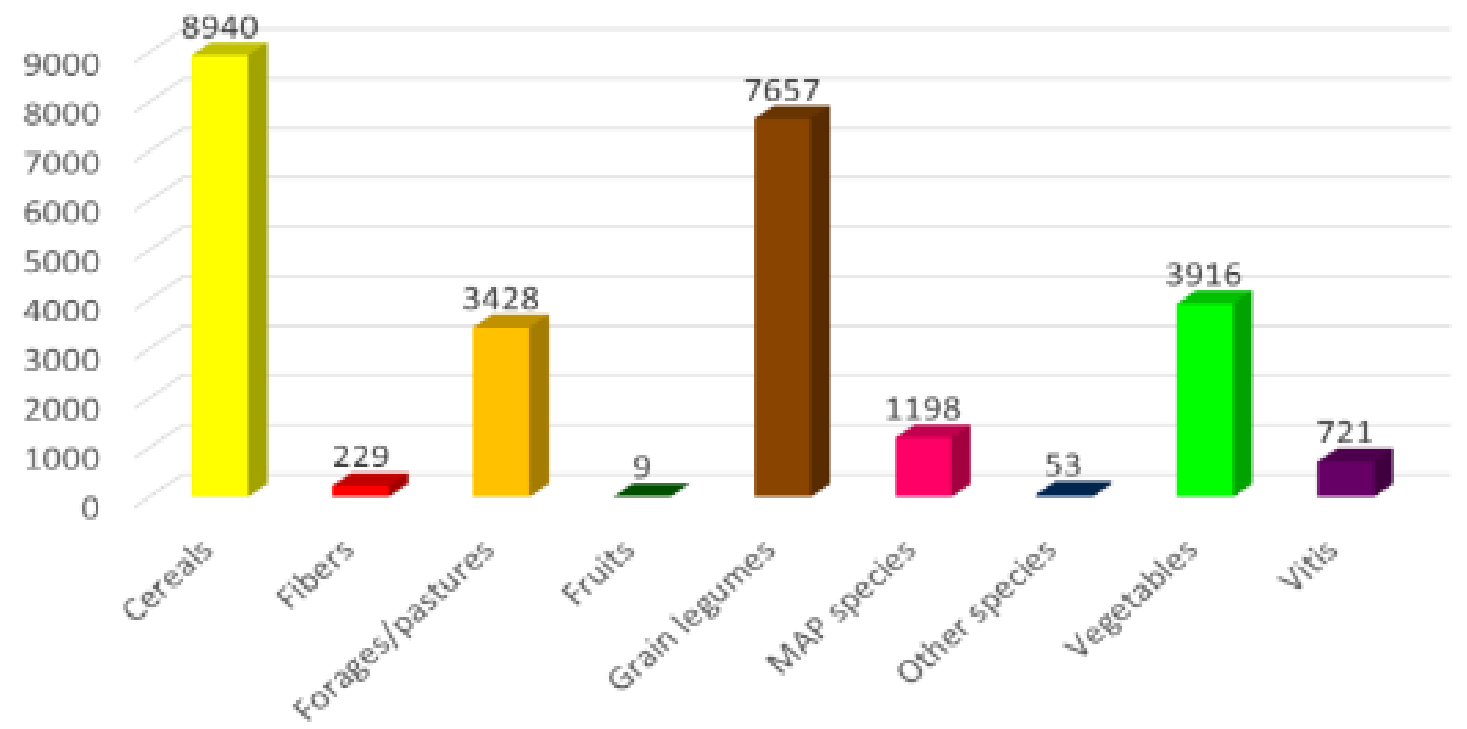

Figure 9: Portuguese collections in EURISCO: Number of accessions by species' group

The "Biological status" of the accessions of the Portuguese collections in EURISCO, are represented as a percentage of the total number of accessions, are represented here (figure 10). In terms of the "Biological status" the most represented, are Landraces $(58,94 \%)$ followed by Wild $(15,25 \%)$, Breeding/Research Material (14,14\%), Unknown (10,75\%), Advanced/improved cultivar $(0,73 \%)$ and Weedy $(0,19 \%)$. 


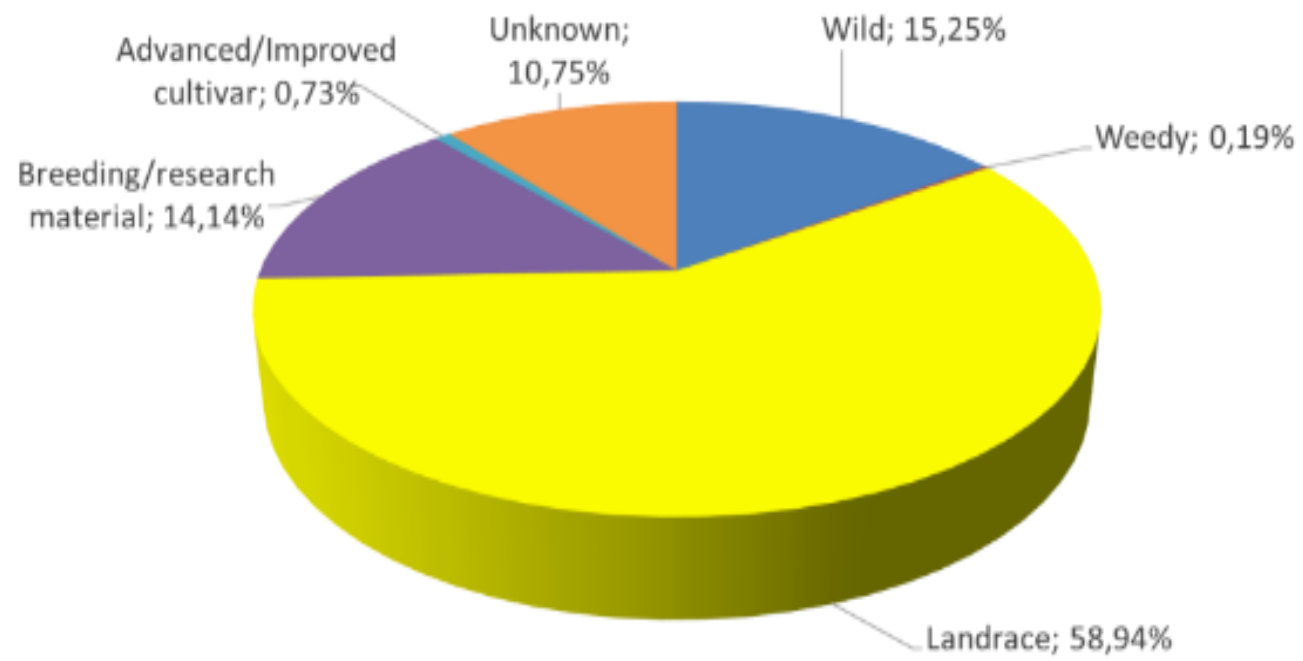

Figure 10: Portuguese collections in EURISCO: Biological status percentage of the total number of accessions

The "Acquisition source" of Portuguese collections in EURISCO are represented as percentage of the total number of accessions (Figure 11). In terms of the "Acquisition source" the most represented are Farm store and Farm or cultivated habitat followed by Field, Unknown, Wild Habitat, Fallow land, Backyard or home garden and Market or shop.
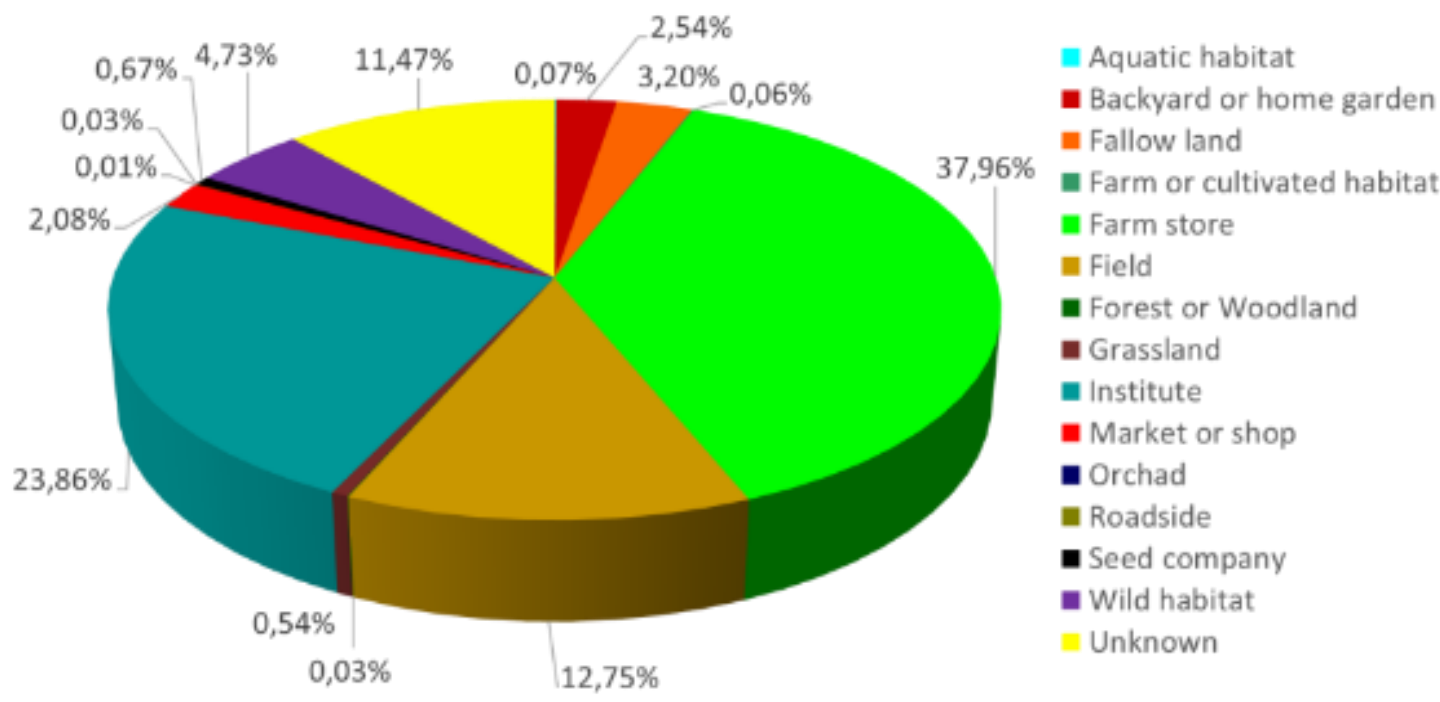

Figure 11: Portuguese collections in EURISCO: Acquisition source percentage of the total number of accessions

The "Country of origin" of the Portuguese collections in EURISCO, is represented as a percentage of the total number of accessions (Figure 12).

Although the Portuguese germplasm collections includes material originated from 32 countries, the most represented is Portugal followed by Spain. 
Material of unknown origin represents $14,43 \%$ of the total, showing that it is important to gap filling for the missing information

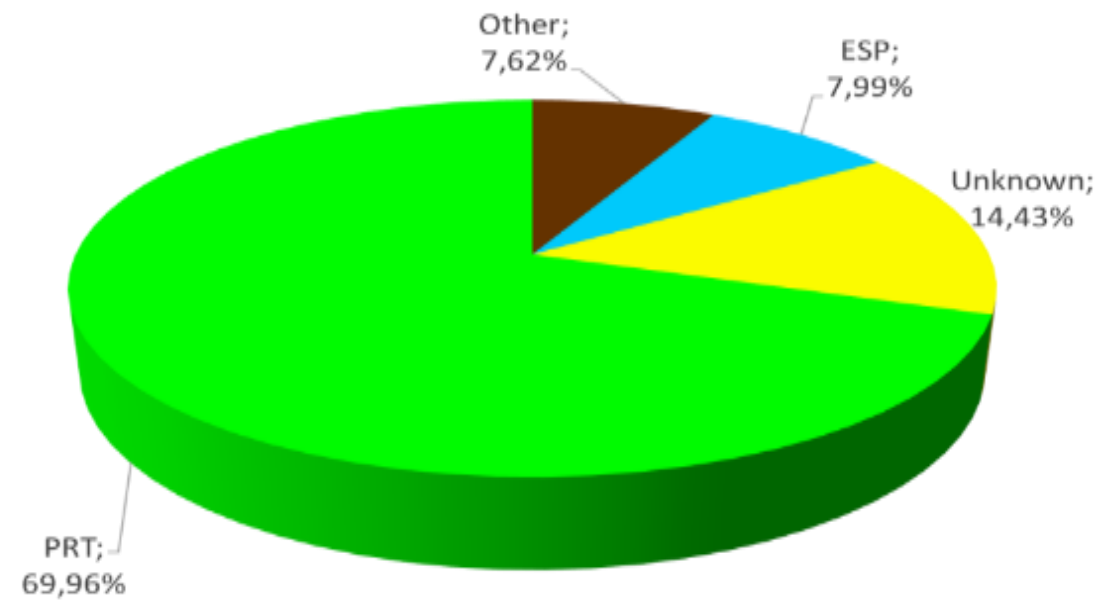

Figure 12: Portuguese collections in EURISCO: Country of origin percentage of the total number of accessions

The "Type of Collection" of the accessions of the Portuguese collections in EURISCO, are represented as a percentage of the total number of accessions (Figure 13). In terms of the "Type of Storage" the most represented, are Long-term (47\%) followed by Medium-term (45\%), Field collection $(5 \%)$ and Unknown (3\%).

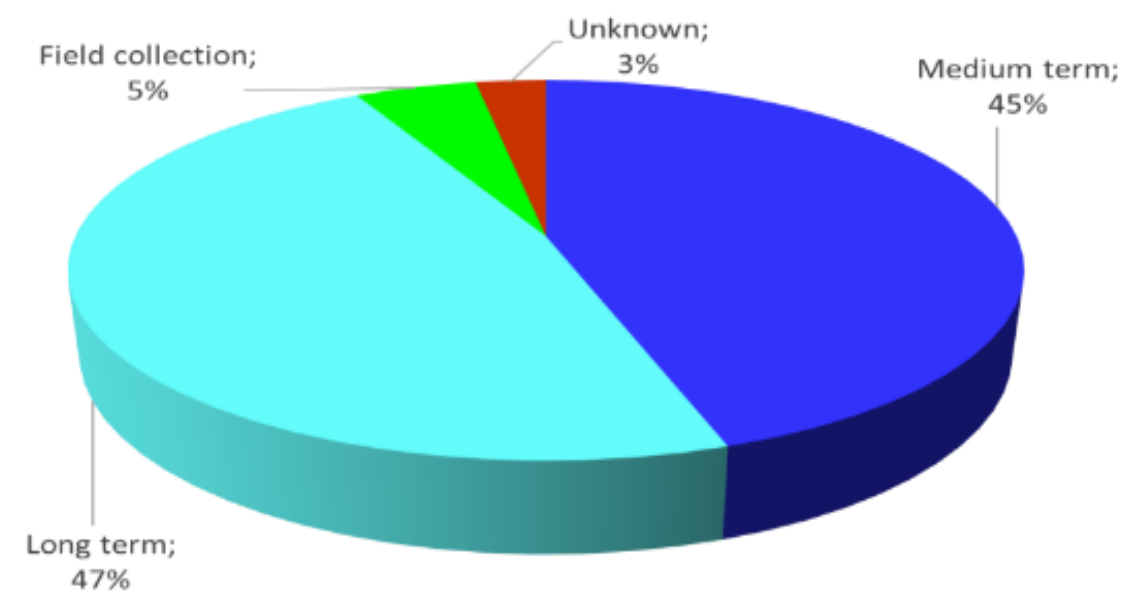

Figure 13: Portuguese collections in EURISCO: Type of Collection percentage of the total number of accessions

Concerning to the near future it is planned to upload more information to EURISCO from:

\section{- PRT102- ISOPLEXIS}

1) Passport data $-1,190$ accessions

- PRT001 - BPGV

1) Passport data $-3,183$ accessions

2) Characterization date -6 crop and 36,867 observation 
Presently, the main goal to achieve in Portugal is to implement the Grin-Global Platform at the national level. To achieve this main goal the following have already been achieved:

- "2018 Grin-Global and Genesys Workshop", 4-8 June 2018, organized by the Global Crop Diversity Trust and BPGV, in Porto, Portugal

- Workshop "Implementation of the Grin-Global Platform at the National level", 25-27 September 2018, organized by BPGV, in Braga, Portugal.

\section{Conclusions}

Implementing Grin-Global platform at national level will promote, facilitate and enable access and interoperability between documentation systems, giving wider access to existing genetic material maintained in the country.

When implemented at the national level, the Grin-Global platform will consolidate the Portuguese National Programme on Plant Genetic Resources, with all the national stakeholders directly involved in the conservation of plant genetic resources.

The integration of all national collections into the Grin-Global platform will contribute to a more complete and updated Portugal National Inventory of Plant Genetic Resources.

The Grin-Global platform allows you to upload new data or to update existing data from the Portuguese National Inventory to EURISCO and that the available information is in greater quantity and quality, in a short period of time.

\section{Acknowledgements}

I wish to thank Ana Maria Barata and Eliseu Bettencourt for their review and critical reading.

\section{References}

[1] A.M. Barata, F. Rocha, J. Oliveira, Lima J.M., H. Nobrega, M.A.A. Pinheiro de Carvalho, Sónia Dias. 2014a. Implementation of a PGR Global Documentation System in Portugal. In S. Dias, E. Dulloo, N. Maxted, S. Kell, E. Thörn, L. Smith, J. Preston, S. Hutchinson. (ed.) International Conference on Enhanced Genepool Utilization - Capturing wild relative and landrace diversity for crop improvement, Cambridge, United Kingdom, 16-20 June 2014. Book of Abstracts. Bioversity International, Rome, Italy, pag. 73-74.

[2] A.M. Barata, F. Rocha, V. Lopes, R. Maia de Sousa, E. Eiras Dias, B. Maçãs. 2014b. National programme for plant genetic resources - a platform of cooperation in Portugal. In S. Dias, E. Dulloo, N. Maxted, S. Kell, E. Thörn, L. Smith, J. Preston, S. Hutchinson. (ed.) International Conference on Enhanced Genepool Utilization - Capturing wild relative and landrace diversity for crop improvement, Cambridge, United Kingdom, 16-20 June 2014. Book of Abstracts. Bioversity International, Rome, Italy, pag.120-121.

[3] E. Bettencourt. 1996. The Portuguese "National Information System on Plant Genetic Resources" (SNIRGV). EUCARPIA Genetic Resources Section Meeting. Genebank Documentation, The users perspective. Institute for Agrobotany, Budapest, Hungary, 17-19 October, 1996

[4] Bioversity International (2015). New era of plant genetic resource management for Portugal. Available at: 
http://www.bioversityinternational.org/news/detail/a-new-era-of-plant-genetic-resourcemanagement-for-portugal/ (accessed 26 September 2018).

[5] EURISCO. 2018. European Search Catalogue for Plant Genetic Resources (EURISCO) Available at: https://eurisco.ipk-gatersleben.de/apex/f?p=103:55:::NO: (accessed 26 September 2018).

[6] FAO. 2009. International Treaty on Plant Genetic Resources for Food and Agriculture, FAO 2009. Available at: http://www.fao.org/3/a-i0510e.pdf (accessed 26 September 2018).

[7] F. Rocha 1999. Documentação e Informação no BPGV - Princípios Gerais. I Conferência Técnica sobre Recursos Genéticos Vegetais, Braga 3 a 5 de Junho de 1996. Banco Português de Germoplasma Vegetal (BPGV), Braga, Portugal, pag 103- 112. DOI: 10.13140/2.1.2002.5927.

[8] GRIN-GLOBAL. 2018. The GRIN-Global Project. Available at: https://www.grin-global.org/ (accessed 26 September 2018).

[9] ICNF. 1998. Convention on Biological Diversity (CBD). First Portuguese National Report. 117 pag.

[10] INIAV. 2015a. A nova era da gestão dos recursos fitogenéticos para Portugal. Available at: http://www.iniav.pt/noticias/banco-portugues-de-germoplasma-vegetal-(bpgv) (accessed 26 September 2018).

[11] INIAV. 2015b. Programa Nacional para os Recursos Genéticos Vegetais. Available at: http://www.iniav.pt/fotos/editor2/pnrgv_web.pdf (accessed 26 September 2018).

[12] INIAV. 2018a. BPGV GRIN-Global. Available at: http://www.iniav.pt/menu-de-topo/quemsomos/unidades-de-investigacao-e-servicos/biotecnologia-e-recursos-geneticos/recursosgeneticos-vegetais-plataforma-on-line (accessed 26 September 2018).

[13] INIAV.2018b. BPGV GRIN-Global. Website. Available at: http://bpgv.iniav.pt/gringlobal/search.aspx (accessed 26 September 2018).

[14] Miguel A. A. Pinheiro de Carvalho and Humberto Nóbrega. 2013. The implementation of GRINGlobal as the documentation system in the ISOPlexis Genebank, Madeira, Portugal. E-Bulletin January 2013 - EURISCO. Available at: http://www3.uma.pt/isoplexis/noticias/13-botetimeurisco-art-isoplexis.pdf (accessed 26 September 2018).

[15] Compilation of the communications presented in: EURISCO Training Workshop. National Focal Points Regional Training Workshop for Southeast Europe, Tirana, Albania, 19-21 May 2015 and EURISCO National Focal Points Training Workshop, 9-11 October 2018, Gatersleben, Germany.

*Corresponding author.

E-mail address: filomena.rocha@ iniav.pt 